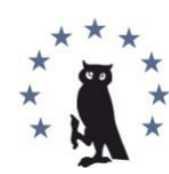

Copyright (C) 2021 by Cherkas Global University All rights reserved.

Published in the USA

European Journal of Contemporary Education

E-ISSN 2305-6746

2021. 10(4): 897-911

DOI: $10.13187 /$ ejced.2021.4.897

https://ejce.cherkasgu.press

IMPORTANT NOTICE! Any copying, reproduction, distribution, republication (in whole or in part), or otherwise commercial use of this work in violation of the author(s) rights will be prosecuted in accordance with international law. The use of hyperlinks to the work will not be considered copyright infringement.

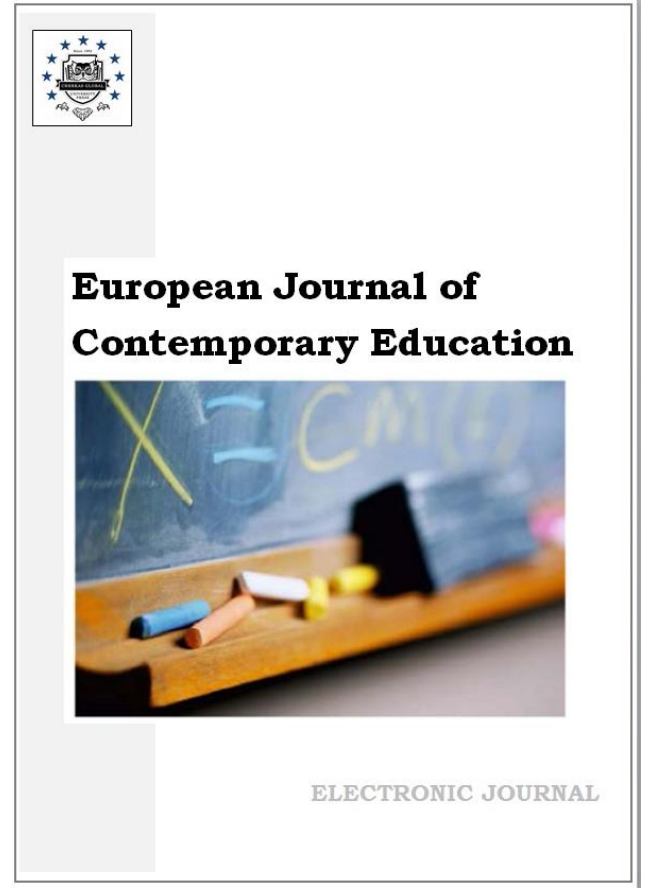

\title{
Financial Literacy Level: An Empirical Study on Savings, Credit and Budget Management Habits in High School Students
}

\author{
Arturo García-Santillán a, *, Lizzeth, Navarro-Ibarra ${ }^{b}$, Violetta S. Molchanova ${ }^{c, d}$, \\ Dalia Lizeth Quijano Castro ${ }^{\mathrm{e}}$ \\ ${ }^{a}$ UCC Business School at Universidad Cristóbal Colón, Veracruz, México \\ b Instituto Tecnológico de Sonora, México \\ ${ }^{\mathrm{c}}$ Cherkas Global University, Washington, USA \\ d Volgograd State University, Volgograd, Russian Federation \\ e UCC Business School at Universidad Cristóbal Colón, Veracruz, México
}

\begin{abstract}
In the majority of the countries, have exposed the need for people to have a higher level of financial education, which translates into better habits for saving and investing, in addition, they will have better decisions for the management of their personal finances which is translates into financial well-being, therefore, the aim of this work was to evaluate the financial literacy of high school students about saving habits, budgeting and credit; as well as, identify if it differs by gender. To do this, the hypothetical-deductive method is used, based on the seminal works of Bernheim, Garrett and Maki (2001) and Lusardi and Mitchell (2011). The sample is non-probabilistic by selfdetermination, therefore 256 students from four institutions participated in the Veracruz context, were surveyed. For the data descriptive analysis, in order to describe the main frequencies in each saving, credit and budget indicator, the cross table's procedure was carried out. To test hypothesis about gender differences, one-way ANOVA and Levene's test was applied. The main findings show slight differences between gender in some fundamental aspects of saving, credit and the use and management of the budget.
\end{abstract}

Keywords: credit, budget, savings.

\footnotetext{
${ }^{*}$ Corresponding author

E-mail addresses: agarcias@ucc.mx (A. García-Santillán)
} 


\section{Introduction}

To understand the object of the study it is important to define, what's financial literacy? therefore, according to Del Río-Chivardi, Suárez-Luengas and Castro-Solares (2019) is the combination of the awareness, knowledge, skills and behaviors necessary to make sound financial decisions and over time achieve the financial well-being of the individual himself. Personal financial well-being is of the most importance for the development of activities throughout life. The value of financial education is based on the knowledge that people has to obtain greater benefits by making informed decisions, as well as the skills for active participation in a stable and rising economic life, thus taking advantage of the opportunities that arise (Del Río-Chivardi et al., 2019).

In Bolivia the concern of the cognitive state about finances is also taken into account in order to decisions that are carried out in this area, from which, Roa, Garrón and Barboza (2018) point out that the skills of mathematical thinking, in particular, they are closely related to making the right financial decisions for prosperity.

On the other hand, Starček and Trunk (June, 2013) refer that the recent economic crisis showed that individuals have a low average financial literacy and insufficient financial experience. Financial markets are increasingly difficult; hence, the people must have the education, information and knowledge about the actions of their finances and the proper use of them.

Similarly, in the United States consumers lack the financial knowledge necessary to make important decisions in their finances and to be able to improve their interests. Bernheim, Garrett, and Maki (2001) reported that middle-aged people who assumed personal financial management, and in turn took a course in high school, aimed to save a greater proportion of their income than others who did not.

Villagómez (2014) analyzed financial literacy in young people who were attending a high school in Mexico; their results show that they do not have financial knowledge, in particular women and students who are enrolled in public schools. In this way, he demonstrated in his research that a fifth of young people do not understand basic concepts of economics, such as inflation, interest rates, among others. In addition, young people show disinterest in their finances and learning from them.

For their part, Martínez-Morales and Franco-Flores (2016) mention that the issue of economic and financial education began to generate relevance after the 2008 crisis in the United States and its effect on the Mexican economy. In their study, they concluded that it can be recommended to implement economic and financial education courses for the correct decisionmaking in young people, within the curriculum of both university and senior high school level, but the support of parents and the experience obtained every day.

A study carried out in Veracruz by Moreno-García, García-Santillán and Gutiérrez-Delgado (2017) point out that university students do not know how to calculate interest rates, hence when interpreting the information related to the price of bonds where they are involved calculations associated with interest rates, show a low level of financial education. Also, they showed that the student does not consider inflation in the calculation of the devaluation of money, so he does not protect his savings from the effect that it may have on his equity.

Due to the fact that there is still a great lack of financial education in young people in Mexico, according to the studies of Villagómez (2014) and Moreno-García, García-Santillán and GutiérrezDelgado (2017), this work addresses questions about which it is the cause of this apparent lack of financial education. This makes it necessary to review the empirical literature on the different findings in order to identify those potential effects that this lack of financial knowledge brings with it, in order to be in a position to generate proposals that help to reverse this phenomenon under study.

It should be remembered that in order to make adequate decisions in the matter of personal finances it is essential to be clear about the knowledge and capacities that people have in the matter of finances and thus have better arguments that lead to an ideal choice of financial instruments to be used.

Therefore, the main question of the study is: what knowledge do senior high school students have in financial education? specifically in topics of saving, budget, and credit. Also, it is questioned whether the level of financial knowledge differs by gender?

\section{Rationale}

Today financial education is an interesting topic for the economic development of all countries, a great topic of interest for young people and adults, since according to the knowledge 
we have about it, it is how we can make better financial decisions for short, medium and long term. For this reason, the reasons for developing this study will be written below.

At the beginning, it is important to mention that many countries are concerned about why a large part of the population does not have an adequate financial education. In this regard, we can cite what the Group of Twenty (G20) has exposed on its agenda as a topic of global interest, and it is precisely the interest of these most powerful countries in the world to carry out one of the main tasks that make up their agenda, we refer to the issue of Financial Inclusion and Financial Education (Álvarez, 2018). This issue has become very relevant and important because as time passes, more population does not have financial services or is not included in the financial systems of their own countries. This has been the trigger for various questions to arise: why does the population lack financial services? And what does it take for the entire population to be included in financial services?

In the area of Financial Education, many studies have been carried out which give us a significant contribution to the empirical evidence on this topic. Although there is a solid body of theory and empirical evidence on the economics and financial education, it would be desirable to elaborate more questions about, how people are acquiring financial knowledge and, if it is put into practice, which necessarily encompasses the topic of financial literacy.

In recent years, studies have been developed with the purpose to examine how financial literacy is linked to financial knowledge, in terms of saving and investment behavior. On these works we can cite the studies of Bernheim, Garrett, and Maki, (2001), Starček and Trunk (June, 2013), Villagómez (2014), Martínez-Morales and Franco-Flores (2016), Cruz-Vargas, Díaz-Navarro and Célleri-Zúñiga (2017), Moreno-García, García-Santillán and Gutiérrez-Delgado (2017), Roa, Garrón and Barboza (2018), Del Río-Chivardi, Suárez-Luengas and Castro-Solares (2019). All these theorists and researchers have favored from their knowledge in the field of financial education, hence the results of this work are expected to provide evidence that will add to the field of knowledge about the level of financial literacy in terms of saving habits, budget and credit at the high school level. This in turn will allow design strategies to improve the level of financial education in high school students.

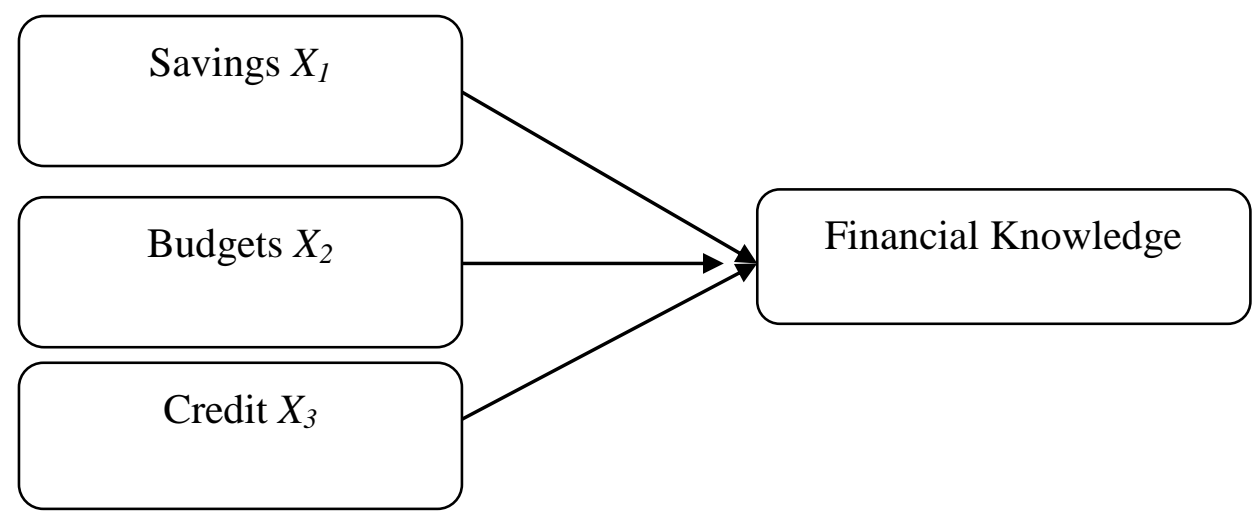

Fig. 1. Path of the model for the empirical study (construct)

\section{Discussion}

On the subject of financial education, several studies have been carried out in the last decade, all of them, with the fundamental purpose to identify the level of literacy in the different populations studied. On this topic Van Rooij, Lusardi and Alessie (2011) carried out an investigation in 200o Dutch households. As a result, they found that the low level of financial education in the population causes insecurity in people to invest in the stock market. This generates little risk diversity in their savings and deprives people to obtain a higher return on their assets by not taking advantage of the financial instruments offered by banking and financial institutions.

Similar analysis was carried out by Lusardi and Mitchell (2011), focusing on the populations of Germany, Japan, Italy, Sweden, the Netherlands, New Zealand, Russia and the United States, considered as populations with acceptable levels of financial education, capable of taking good decisions regarding financial products and services. However, the results obtained showed that the populations presented a deficient level of financial education, which makes decision-making in this 
matter inefficient, and consequently, could negatively affect their personal and family financial situation.

A study carried out by Zamora-Lobato, Moreno-García, Córdova-Rangel and García-Santillán (2016) in the city of Xalapa, Veracruz in Mexico with 401 high school students, showed that students have the basic knowledge to perform arithmetic operations. However, the lack of knowledge in financial operations is evident, and they ignore concepts such as inflation and the value of money over time. Therefore, these young people can make unfavorable decisions regarding investments, savings, credit, insurance and pensions, expenses, and budgeting.

In Colombia, Pacheco and Yaruro (2017) analyzed the factors that affect the use of financial products with data from the Survey for the Measurement of Financial Capabilities in the Andean Countries. The result showed that people with higher education than the average of the population and with a higher level of income, are more likely to know and own a financial product. Furthermore, gender and age do not present a marked relationship with the possession of financial products.

On the subject of financial knowledge on issues associated with savings, credit and budget management habits, significant findings have been reported, which support the thesis that financial preparation plays a very important role in retirement. The knowledge and management of the issues associated with saving, have a relationship with financial education. Probably one of the findings that have been referred to as one of the most solid, is the one reported by Adams and Rau (2011) who support the thesis that the cognitive factor plays a determining role in people's financial training.

In addition, saving is synonymous with the accumulation of wealth and the habit of people towards this financial topic, turns out to be positive. In this regard, Jianakoplos and Bernasek (1998) showed that there is less willingness to take risks on the part of women compared to men, which allows us to say that there are gender differences in wealth accumulation on this issue.

Nowadays, reforms to the pension system in Mexico expose the need for workers to save for retirement. On this, Lusardi and Mitchell (2014) point out that it is increasingly required that people decide how much to save and also must assume during retirement, the responsibility of carefully managing so that their assets last a lifetime and at the same time satisfy their needs. It is therefore important to have financial knowledge that helps increase people's ability to make informed decisions.

\section{Methodology}

The study is a non-experimental design, descriptive and cross-sectional. The study seeks, based on data analysis, to describe the distinctive characteristics between men and women, about the knowledge they have in relation to saving habits, budget management and credit issues. The surveyed population attends the high school level, whose ages range between 15 and 18 years. They belong to the schools: Centro de Estudios Tecnológicos del Mar o7 (CETMAR), Escuela Reyes Heroles, Colegio de Bachilleres del Estado de Veracruz 62 (COBAEV), Colegio Madrid, Colegio Cristóbal Colon and Colegio Atlántico. As general characteristics of the population, most of the students have the financial support of their parents and reside in the city of Veracruz and Boca del Río.

The sample kind is non-probabilistic by self-determination, that is, communication was established with the participating institutions and the survey was provided to them in electronic format. The total participants were 280 students, of which 24 surveys were canceled because were incomplete. The composition of the sample by participating school was as follows: 50 students from CETMAR 07; 60 from Escuela Reyes Heroles; 40 from COBAEV 62; 60 from Colegio Madrid; 40 from Colegio Cristóbal Colon and 30 from Colegio Atlántico.

The questionnaire used was designed from some items consulted from the survey on financial education designed by Moreno-García, García-Santillán, and Gutiérrez (2017), from the Financial Education test from the "Consolidatedcredit" portal (ConsolidatedCredit, 2021), as well as a questionnaire from the "Bancompara" Financial Education (Moreno, 2020). To analyze whether the instrument used is reliable, the Cronbach's alpha coefficient is estimated, which is useful to evaluate the homogeneity of the test items. This coefficient shows values between 0 and 1 , where $o$ means null reliability and 1 total reliability. For this study, an instrument is considered to be reliable when its coefficient is equal to or greater than 0.8 , according to the criterion proposed by Hair et al. (1998). Subsequently, non-parametric statistics are used, specifically the use of cross 
tables to verify the frequencies of each indicator and its comparison between genders. In support of this procedure, analysis of variance (ANOVA) and Levene's test is carried out.

\section{Results}

First, the reliability and internal consistency were calculated using Cronbach's alpha, from which a value less than 0.6 was obtained and the KS test showed that the data did not come from a normal distribution. Hence, the non-parametric statistical analysis was performed to answer the study question.

Regarding the composition of the sample, there was the participation of $57.8 \%$ of women and $42.2 \%$ of men, whose ages are: 17 years (43.4 \%), 16 years (22.3\%), 18 years $(21.2 \%), 15$ years (9.8 \%), 19 years (2.7 \%). Regarding marital status, $93.8 \%$ are single, $3.9 \%$ live in common law with their partner, $2.3 \%$ are separated and one case is divorced. $75.8 \%$ only study, followed by $19.5 \%$ who in addition to studying also work, $3.1 \%$ do not have a job, and $1.6 \%$ only work.

Finally, $89.1 \%$ indicate that they receive less than $\$ 1,500.00$ in monthly income, which, without a doubt, refers to the scholarship provided by the government to young people who study high school, $7.4 \%$ receive from $\$ 1,500.00$ to $\$ 3,000.00,2.3 \%$ from $\$ 3,000.00$ to $\$ 4,999.00$ and the remaining $1.2 \%$ more than $\$ 5,000.00$ of monthly income. Now the descriptives of the instrument indicators are shown in Table 1.

Table 1. Descriptive indicators

\begin{tabular}{lrrrr}
\hline & $\mathrm{N}$ & $\mu$ & \multicolumn{2}{c}{ Std. Dev. } \\
\hline How much do you earn or receive from your work, activity or & 256 & 1.156 & .50000 \\
business? & 256 & 3.558 & 2.52448 \\
What is saving? & 256 & 2.726 & 1.32969 \\
What is the main reason why you save or would save? & 256 & 2.343 & .56621 \\
How often do you usually read or find out about savings accounts, & 256 & 2.363 & .92294 \\
investments, credit and retirement funds? & 256 & 2.378 & 1.54189 \\
How much money should you put in your savings monthly? & 256 & .0859 & .28082 \\
For you the credit is? & 256 & 2.320 & .64999 \\
Accounts with some type of credit? & 256 & .1094 & .31272 \\
What is the main risk of borrowing money? & 256 & 4.300 & 1.48171 \\
Accounts credit card? & 256 & 2.886 & 1.64462 \\
In case of an affirmative answer above, select how many of them? & & & \\
What is the maximum time of your income that you should allocate & 256 & 2.355 & 1.34113 \\
to pay your credit cards? & 256 & 1.523 & .80649 \\
What is the maximum debt-to-income ratio you should have to & 256 & .3672 & .48298 \\
maintain financial stability? & 256 & .3477 & .47716 \\
How do you prefer to handle your money? & 256 & .3008 & .45950 \\
Knows how your monthly income is composed? & &
\end{tabular}

In relation to the frequencies observed in the indicators on the subject of saving, Table 2 shows the percentages obtained and their comparison by gender. The specific indicators of saving are: What is saving?, what is the main reason why they save or would save?, the frequency with which they usually read or learn about savings accounts, investments, credit and retirement funds.

Table 2. Knowledge about aspects of saving

\begin{tabular}{lccccc}
\hline What's saving & Male & Female & Frequency & $\%$ & $\% \Sigma$ \\
\hline Save money & 30 & 58 & 88 & 34,4 & 34,4 \\
Have money for emergencies & 10 & 24 & 34 & 13,3 & 47,7 \\
Something for the future & 12 & 18 & 30 & 11,7 & 59,4 \\
Don't spend & 0 & 2 & 2 &, 8 & 60,2
\end{tabular}




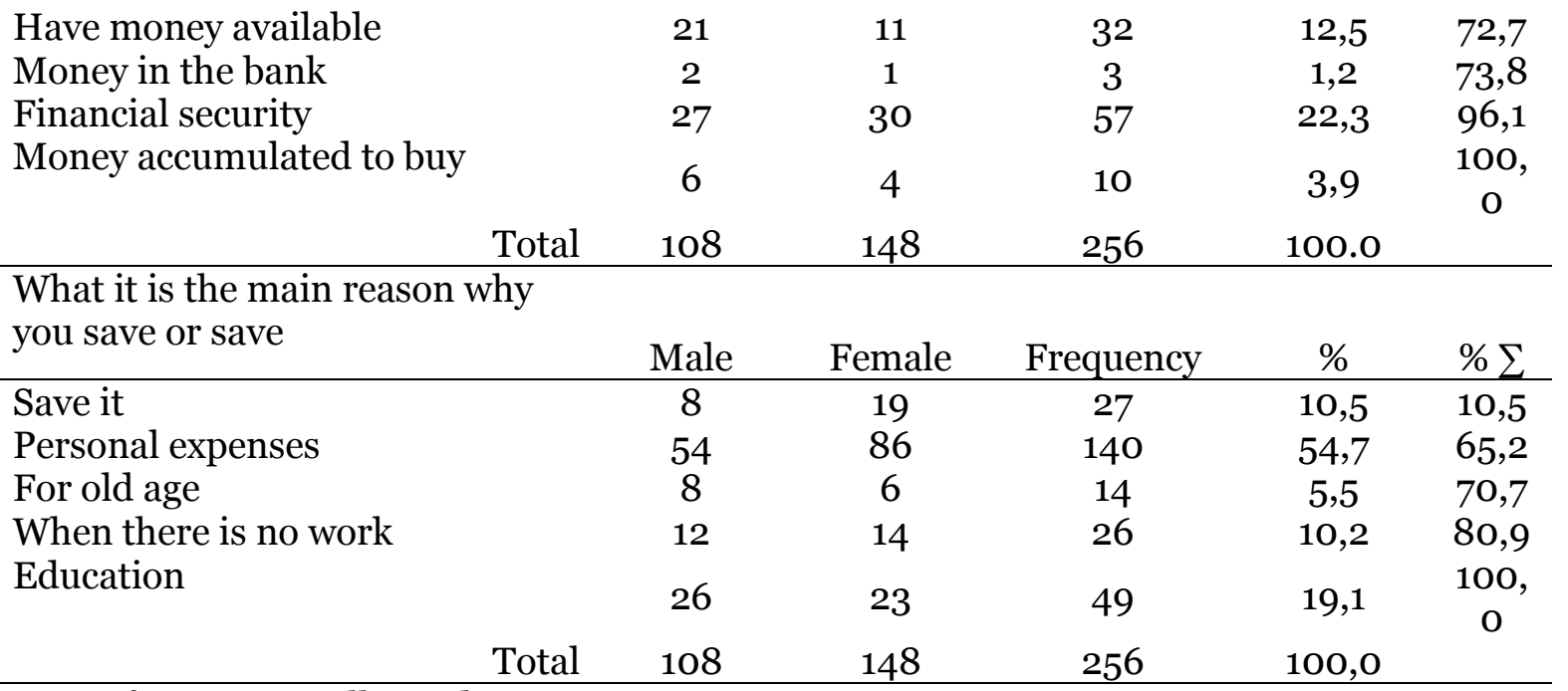

How often you usually read or inquire about savings account, investments, credit and

\begin{tabular}{|c|c|c|c|c|c|}
\hline \multirow{4}{*}{$\begin{array}{l}\text { retirement funds } \\
\text { Always } \\
\text { Sometimes } \\
\text { Never }\end{array}$} & Male & Female & Frequency & $\%$ & \multirow{2}{*}{$\frac{\% \sum}{4,7}$} \\
\hline & 4 & 8 & 12 & 4,7 & \\
\hline & 70 & 74 & 144 & 56,3 & 60,9 \\
\hline & 34 & 66 & 100 & 39,1 & $\begin{array}{c}100, \\
0\end{array}$ \\
\hline Total & 108 & 148 & 256 & 100,0 & \\
\hline $\begin{array}{l}\text { How much money should put } \\
\text { into your savings month }\end{array}$ & Male & Femal & reguncy & $\%$ & $\% \Gamma$ \\
\hline $2 \%$ of their income & 10 & 26 & 36 & 14,1 & 14,1 \\
\hline $10 \%$ of their salary & 65 & 69 & 134 & 52,3 & 66,4 \\
\hline $\begin{array}{l}\text { All money that fits the end of the } \\
\text { month }\end{array}$ & 18 & 25 & 43 & 16,8 & 83,2 \\
\hline $\begin{array}{l}\text { Any low denomination banknote } \\
\text { that has }\end{array}$ & 15 & 28 & 43 & 16,8 & 100,0 \\
\hline Total & 108 & 148 & 256 & 100,0 & \\
\hline
\end{tabular}

For the majority of surveyed, the meaning of saving is: to save money, without necessarily having to be a specific place (34,4\% - 88 cases), in the comparison between men and women, the response of women was more (58) than men (30). The main reason why they save or would save, $54,7 \%$ (140 cases) consider it to be for personal expenses, again the highest number of cases in women (86) than in men (54).

Regarding the frequency with which they are used to reading or learning about savings accounts, investments and retirement funds, $56,3 \%$ do it sometimes, and again women are slightly more (74) than men (70). Finally, 52,3 \% of the participating students refer that the amount of their income that they should allocate to their savings on a monthly basis should be in the order of $10 \%$ of their salary, the opinion among women is very similar (69) and men (65).

Regarding the frequencies observed in the indicators on the subject of credit, Table 3 shows the percentages obtained and their comparison by gender. The specific indicators are: the definition they have about credit, if they have any type of credit, the risks of having a credit, if they have a credit card and how many they have, and what amounts they consider should be allocated to the payment of credit cards.

The results described in Table 3 show that $46,9 \%$ consider that the credit is a loan (67 women, 53 men), 91,4 \% stated that they do not have any credit (136 women, 98 men). Similarly, they refer that the main risk of requesting a loan is due to the payment or increase of interest (47,7 \%), as well as the fact of getting into debt (42,2 \%). These percentages are very representative, since although $91.4 \%$ indicated that they do not have any credit and $89.1 \%$ state 
that they do not have credit cards, which are closely associated with the type of risk involved in the use of these credits, previously indicated by the participants of this study. Now, $10.9 \%$ of the cases stated that they had a credit card, $15.2 \%$ reported they had 1 or 2 ; only $2 \%$ said they had between 3 or $4,1.6 \% 5$ or 6 and the rest $81.3 \%$ did not apply.

Table 3. Indicators credit

\begin{tabular}{|c|c|c|c|c|c|}
\hline $\begin{array}{l}\text { For you, what's } \\
\text { credit? }\end{array}$ & Male & Female & Frequency & $\%$ & $\% \sum$ \\
\hline A loan & 53 & 67 & 120 & 46,9 & 46,9 \\
\hline A debt & 21 & 19 & 40 & 15,6 & 62,5 \\
\hline A problem & 2 & 5 & 7 & 2,7 & 65,2 \\
\hline Economic aid & 20 & 37 & 57 & 22,3 & 87,5 \\
\hline Don’t know & 12 & 20 & 32 & 12,5 & 100,0 \\
\hline $\begin{array}{l}\text { Do you have some } \\
\text { credit? }\end{array}$ & Male & Female & Frequency & $\%$ & $\% \sum$ \\
\hline Don't & 98 & 136 & 234 & 91,4 & 91,4 \\
\hline Yes & 10 & 12 & 22 & 8,6 & 100,0 \\
\hline $\begin{array}{l}\text { What is the main } \\
\text { risk of borrowing } \\
\text { money }\end{array}$ & Male & Female & Frequency & $\%$ & $\% \sum$ \\
\hline $\begin{array}{l}\text { Not pay and lose } \\
\text { equity }\end{array}$ & 8 & 18 & 26 & 10,2 & 10,2 \\
\hline $\begin{array}{l}\text { Pay high interest or } \\
\text { increased interest }\end{array}$ & 53 & 69 & 122 & 47,7 & 57,8 \\
\hline Borrowing & 47 & 61 & 108 & 42,2 & 100,0 \\
\hline $\begin{array}{l}\text { Do you have a credit } \\
\text { card? }\end{array}$ & Male & Female & Frequency & $\%$ & $\% \sum$ \\
\hline Don’t & 98 & 130 & 228 & 89,1 & 89,1 \\
\hline Yes & 10 & 18 & 28 & 10,9 & 100,0 \\
\hline $\begin{array}{l}\text { If you have a credit } \\
\text { card, how many? }\end{array}$ & Male & Female & Frequency & $\%$ & $\% \sum$ \\
\hline 1 or 2 & 16 & 23 & 39 & 15,2 & 15,2 \\
\hline 3 or 4 & 3 & 2 & 5 & 2,0 & 17,2 \\
\hline 5 or 6 & 1 & 3 & 4 & 1,6 & 18,8 \\
\hline Not applicable & 88 & 120 & 208 & 81,3 & 100,0 \\
\hline
\end{tabular}

Regarding the question about what is the maximum amount that they consider to allocate from their income to the payment of their cards, of course, this is regardless of the previous results, 38,3 \% declared themselves as none, which does not make it clear how much they would pay. In other results $26,2 \%$ indicate that will pay the needed amount to pay off the balance each month, followed by $22,7 \%$ who consider that no more than $10 \%$ of their income and the remaining $12,9 \%$ say that no more than $30 \%$ of their income (Table $3 \mathrm{~b}$ ).

Table 3b. Indicators Credit

What is the maximum amount of your income that should be allocated to paying their credit cards

None

No more than $10 \%$ of all income Male Female Frequency

34

64

98

\begin{tabular}{cc}
$\%$ & $\% \sum$ \\
\hline 38,3 & 38,3 \\
22,7 & 60,9 \\
12,9 & 73,8
\end{tabular}


income

All that is needed to pay your

debts in full each month

31

36

67

26,2

100,0

Total

$108 \quad 148$

256

100.0

Finally, the subject of the budget is analyzed. This financial tool is a useful tool for the correct use and management of money and spending. Table 4 shows the results on the opinion of the participants on specific aspects related to debt, income, and what it should maintain for financial stability. In the same way, it is questioned how they prefer to handle their money, how their income is integrated, if they usually keep a record of their income and expenses, and if they plan how to distribute their money.

Table 4. Indicators budget

What is the maximum debt-income ratio should be to maintain financial stability

\begin{tabular}{lccccc} 
& Male & Female & Frequency & $\%$ & $\% \sum$ \\
\hline No more than 27\% & 50 & 58 & 108 & 42,2 & 42,2 \\
No more than $41 \%$ & 19 & 22 & 41 & 16,0 & 58,2 \\
No more than the 50 \% & 6 & 9 & 15 & 5,9 & 64,1 \\
As long as you have more money than & & & & & \\
debt, that's okay! & 33 & 59 & 92 & 35,9 & 100,0 \\
Total & 108 & 148 & 256 & 100,0 & \\
\hline How want manage your money & Male & Female & Frequency & $\%$ & $\% \sum$ \\
\hline Cash & 72 & 101 & 173 & 67,6 & 67,6 \\
Credit card & 12 & 20 & 32 & 12,5 & 80,1 \\
Debit Card & 24 & 27 & 51 & 19,9 & 100,0 \\
Total & 108 & 148 & 256 & 100,0 & \\
\hline You know how are your monthly income & & & & & \\
compounds & Male & Female & Frequency & $\%$ & $\% \sum$ \\
\hline No & 56 & 106 & 162 & 63,3 & 63,3 \\
Yes & 52 & 42 & 94 & 36,7 & 100,0 \\
Total & 108 & 148 & 256 & 100,0 & \\
\hline Usually keep track of your debts, & & & & & \\
expenses, income and savings & Male & Female & Frequency & $\%$ & $\% \sum$ \\
\hline No & 74 & 93 & 167 & 65,2 & 65,2 \\
Yes & 34 & 55 & 89 & 34,8 & 100,0 \\
Total & 108 & 148 & 256 & 100,0 & \\
\hline Do you plan the distribution of money & Male & Female & Frequency & $\%$ & $\% \sum$ \\
\hline No & 84 & 95 & 179 & 69,9 & 69,9 \\
Yes & 24 & 53 & 77 & 30,1 & 100,0 \\
Total & 108 & 148 & 256 & 100,0 & \\
\hline & & & & & \\
\hline
\end{tabular}

The result on the opinion that students have in relation to the balance that must be had between income and debt, seems to be highly concentrated in that it should be no greater than $27 \%$, according to $42,2 \%$ of those surveyed, where male and women seem to agree on the same opinion. In another very significant percentage (35,9\%), they consider that it is better to have more money than debt. In this last percentage, more women (59 cases) than men (33 cases) share this 
opinion. On the other hand, 67,6 \% prefer to handle their money in cash (101 women and 72 men). While $63,3 \%$ mention that they do not know how their monthly income is composed.

Finally, $65.2 \%$ said they do not keep any type of record of their debts, expenses, income and savings (women 93, men 74). Another significant data is the $69,9 \%$ of the participants who do not usually plan the distribution of their money, where women (95) outnumber men (84).

For the hypothesis testing about H1: The students' financial knowledge in the topics about saving habits, budget management, and credit, differs by gender, one-way ANOVA is used. This statistic procedure allows us to know the statistic $\mathrm{F}$ and the corresponding $\rho$-value, as well as, to test the hypothesis of equality of means and the test of homogeneity of variances with the Levene's statistic with df1 and df2 for the hypothesis of equality of population variances (Tables 5 and 6).

Table 5. ANOVA test

\begin{tabular}{|c|c|c|c|c|c|c|}
\hline & & $\begin{array}{l}\text { Sum of } \\
\text { squares }\end{array}$ & df & $\begin{array}{l}\text { Quadratic } \\
\text { mean }\end{array}$ & $\mathrm{F}$ & p-value. \\
\hline \multirow[t]{3}{*}{ 1. What is saving } & $\begin{array}{l}\text { Between } \\
\text { groups }\end{array}$ & 49,639 & 1 & 49,639 & 8,003 & 0,005 \\
\hline & Within groups & 1575,482 & 254 & 6,203 & & \\
\hline & Total & 1625,121 & 255 & & & \\
\hline \multirow{3}{*}{$\begin{array}{l}\text { 2. What is the main } \\
\text { reason why you save or } \\
\text { would save }\end{array}$} & $\begin{array}{l}\text { Between } \\
\text { groups }\end{array}$ & 8,868 & 1 & 8,868 & 5,096 & 0,025 \\
\hline & Within groups & 441,991 & 254 & 1.740 & & \\
\hline & Total & 450,859 & 255 & & & \\
\hline \multirow{6}{*}{$\begin{array}{l}\text { 3. How often you } \\
\text { usually read or inquire } \\
\text { about savings account, } \\
\text { investments, credit } \\
\text { and retirement funds } \\
\text { 4. How much money } \\
\text { should you put into } \\
\text { your savings monthly }\end{array}$} & among groups &, 813 & 1 & ,813 & $2,55^{2}$ & 0,111 \\
\hline & within groups & 80,937 & 254 & ,319 & & \\
\hline & Total & 81,750 & 255 & & & \\
\hline & $\begin{array}{l}\text { Between } \\
\text { groups }\end{array}$ & ,024 & 1 & ,024 & ,029 & 0,866 \\
\hline & Within groups & 217,190 & 254 & ,855 & & \\
\hline & Total & 217,215 & 255 & & & \\
\hline \multirow[t]{3}{*}{ 5. For you the credit is } & $\begin{array}{l}\text { Between } \\
\text { groups }\end{array}$ & 4,060 & 1 & 4,060 & 1,713 & 0,192 \\
\hline & Within groups & 602,186 & 254 & 2,371 & & \\
\hline & Total & 606,246 & 255 & & & \\
\hline \multirow[t]{3}{*}{$\begin{array}{l}\text { 6. Accounts with some } \\
\text { type of credit }\end{array}$} & $\begin{array}{l}\text { Between } \\
\text { groups }\end{array}$ & , 008 & 1 & ,008 & ,105 & 0,747 \\
\hline & Within groups & 20,101 & 254 & , O79 & & \\
\hline & Total & 20,109 & 255 & & & \\
\hline \multirow{3}{*}{$\begin{array}{l}\text { 7. What is the main } \\
\text { risk of requesting a } \\
\text { loan }\end{array}$} & $\begin{array}{l}\text { Between } \\
\text { groups }\end{array}$ &, 311 & 1 &, 311 &, 735 & 0,392 \\
\hline & Within groups & 107,423 & 254 & ,423 & & \\
\hline & Total & 107,734 & 255 & & & \\
\hline \multirow[t]{3}{*}{ 8. Credit card accounts } & among groups & ,053 & 1 & ,053 & ,537 & 0,464 \\
\hline & groups within & 24,885 & 254 & ,098 & & \\
\hline & Total & 24,938 & 255 & & & \\
\hline \multirow{3}{*}{$\begin{array}{l}\text { 9. If the previous } \\
\text { answer is affirmative, } \\
\text { select with how many } \\
\text { of them? }\end{array}$} & $\begin{array}{l}\text { Between } \\
\text { groups }\end{array}$ & ,004 & 1 & ,004 & ,002 & 0,965 \\
\hline & Within groups & 559,836 & 254 & 2,204 & & \\
\hline & Total & 559,840 & 255 & & & \\
\hline
\end{tabular}




\begin{tabular}{|c|c|c|c|c|c|c|}
\hline \multirow{3}{*}{$\begin{array}{l}\text { 10. What is the } \\
\text { maximum moment of } \\
\text { your income that you } \\
\text { should use to pay your } \\
\text { credit cards? }\end{array}$} & $\begin{array}{l}\text { Between } \\
\text { groups }\end{array}$ & 11,879 & 1 & 11,879 & \multirow[t]{3}{*}{4,451} & \multirow[t]{2}{*}{0,036} \\
\hline & Within groups & 677.836 & 254 & 2.669 & & \\
\hline & Total & 689.715 & 255 & & & \\
\hline \multirow{3}{*}{$\begin{array}{l}11 . \text { What is the } \\
\text { maximum debt-to- } \\
\text { income ratio you } \\
\text { should have to } \\
\text { maintain financial } \\
\text { stability }\end{array}$} & $\begin{array}{l}\text { Between } \\
\text { groups }\end{array}$ & 4.303 & 1 & 4.303 & 2.405 & 0,122 \\
\hline & Within groups & 454.350 & 254 & 1.789 & & \\
\hline & & 458.652 & 255 & & & \\
\hline \multirow[t]{3}{*}{$\begin{array}{l}\text { 12. How do you prefer } \\
\text { to handle your money }\end{array}$} & $\begin{array}{l}\text { Between } \\
\text { groups }\end{array}$ & .193 & 1 & .193 & .295 & 0,587 \\
\hline & Within groups & 165.667 & 254 & .652 & & \\
\hline & Total & 165.859 & 255 & & & \\
\hline \multirow{3}{*}{$\begin{array}{l}\text { 13. Know how your } \\
\text { monthly income is } \\
\text { composed }\end{array}$} & $\begin{array}{l}\text { Between } \\
\text { groups }\end{array}$ & 2,440 & 1 & 2,440 & 10,866 & 0,001 \\
\hline & Within groups & 57,044 & 254 & ,225 & & \\
\hline & Total & 59,484 & 255 & & & \\
\hline \multirow{3}{*}{$\begin{array}{l}\text { 14. You are used to } \\
\text { keeping a record of } \\
\text { your debts, expenses, } \\
\text { income and savings }\end{array}$} & $\begin{array}{l}\text { Between } \\
\text { groups }\end{array}$ & ,201 & 1 & ,201 & ,885 & 0,348 \\
\hline & Within groups & 57,857 & 254 & ,228 & & \\
\hline & Total & 58,059 & 255 & & & \\
\hline \multirow[t]{3}{*}{$\begin{array}{l}\text { 15. Plan a distribution } \\
\text { of your money }\end{array}$} & $\begin{array}{l}\text { Between } \\
\text { groups }\end{array}$ & 1,153 & 1 & 1.153 & 5,558 & 0,019 \\
\hline & Within groups & 52,687 & 254 & ,207 & & \\
\hline & Total & 53,840 & 255 & & & \\
\hline
\end{tabular}

Table 5 of the one-way ANOVA describes the values of the mean root of the intergroups and intragroups with $\mathrm{df} 1=1$ and $\mathrm{df} 2=254$ respectively, the value of the $\mathrm{F}$ statistic with $\mathrm{p}$-value, which indicates that if $\rho<.05$ then rejects the hypothesis of equality of means, otherwise, if it is $>0.05$, equality of means is accepted and there is no significant difference between the groups. Indicators 1, 2, 10, 13 and 15 show high values in the F statistic and their significance level is less than 0.05, which means that, if there is a difference in the means by gender in these previously referenced indicators. This is not the case in the rest of the indicators. In this idea, the test of homogeneity of variance is now developed to calculate the Levene's statistic with $\mathrm{df}_{1}=1$ and df $2=254$ and the significance $(\rho<.5)$.

Table 6. Test of homogeneity of variances

\begin{tabular}{lrrrr}
\hline \multicolumn{1}{c}{ Indicators } & $\begin{array}{c}\text { Levene's } \\
\text { statistic }\end{array}$ & df1 & df2 & Sig. \\
\hline $\begin{array}{l}\text { 1. What is saving? } \\
\text { 2. What is the main reason you save or would save? }\end{array}$ & 4,877 & 1 & 254 &, 172 \\
$\begin{array}{l}\text { 3. How often you usually read or inquire about } \\
\text { savings account, investments, credit and retirement } \\
\text { funds? }\end{array}$ & 8,083 & 1 & 254 &, 043 \\
$\begin{array}{l}\text { 4. How much money should you put into your } \\
\text { savings each month? }\end{array}$ & 5,691 & 1 & 254 &, 005 \\
$\begin{array}{l}\text { 5. For you, what's credit? } \\
\text { 6. Accounts with some type of credit? }\end{array}$ & 4,702 & 1 & 254 &, 031 \\
7. What is the main risk of requesting a loan &, 417 & 1 & 254 &, 519 \\
8. Credit card accounts? &, 560 & 1 & 254 &, 455 \\
& 2,189 & 1 & 254 &, 140
\end{tabular}


9. If the previous answer is affirmative, select with how many of them?

10. What is the maximum moment of your income that you should use to pay your credit cards?

11. What is the maximum debt-to-income ratio you should have to maintain financial stability?

12. How do you prefer to handle your money?

13. They consist know how your monthly income?

14. Usually keep track of your debts, expenses, income and savings?

15. Plan a distribution of your money?

$\begin{array}{rlll}, 004 & 1 & 254 & , 948 \\ , 528 & 1 & 254 & , 468 \\ 2,875 & 1 & 254 & , 091 \\ 1,439 & 1 & 254 & , .231 \\ 24,128 & 1 & 254 & , 000 \\ 3,677 & 1 & 254 & , 056 \\ 24,268 & 1 & 254 & , 000\end{array}$

To the hypothesis testing of equal population variances, the Levene's test of equality of variances was calculated. The criterion establishes, if the critical level (sig.) $\leq 0,05$ the hypothesis of equality of variances is rejected, otherwise if it is greater, the hypothesis of equality of variances is accepted. The values obtained for indicators 2, 3, 4, 5, 13 and 15 are $<0.05$, which suggests that the hypothesis of equality of variances should be rejected, but not in the rest of the indicators. With these data, there is evidence that shows that, in general, there is no difference by gender.

\section{Conclusion}

For the majority of participants, the meaning of saving is saving money; in the comparison, the response from women was greater than in men. The main reason why they save or would save is for personal expenses, with the highest number of cases being women (86) than men (54). They are used to reading or learning about savings accounts, investments, and retirement funds, women are slightly more than men.

In relation to their income and the amount they would allocate monthly for their savings, they believe that it should be $10 \%$, the opinion similar between men (65) and women (69). As we can see, these results are very similar to those reported by Bernheim, Garrett and Maki (2001) who showed that middle-aged people who undertake personal financial management had the purpose of saving a greater proportion of their income than others who did not.

About credit variable, the results obtained indicate that most of the high school students know what a loan is and a high percentage of the participants indicated that they do not have any credit nowadays, because they consider that the main risk of applying for a loan is due to the payment or increase of interest, as well as the fact of getting into debt. In addition, they do not have credit cards, because have an inherent risk associated with credit, such as the payment of very high interest.

In relation to the balance that should prevail between income and debt should be no greater than $27 \%$, where men and women seem to agree on the same opinion. In addition, they prefer to manage their money in cash (101 cases women and $72 \mathrm{men}$ ) and do not know how their income is composed. In addition, they do not keep any type of record of their debts, expenses, income and savings, where the greater emphasis is given on women versus men. Another significant data is $69,9 \%$ of the participants who report that they do not usually plan the distribution of their money, again women outnumber men.

In summary, we can say that the variables savings, credit, and budget management do not constitute a high level of financial knowledge in secondary school students, since they are clear about what saving is, but on the other hand, they request information sporadically on savings accounts, credit and investment. The intention they show towards saving is very low, since they only consider that $10 \%$ of income should be saved.

About the variable credit, they are not having credit, if we consider that they are students of the high school level. Regarding the use and management of budgets, they do not keep track of their expenses and income, as well as, they do not plan the distribution of their income. The results in relation to the variable savings differ from those presented by Starček and Trunk (2013) who argue that the economic crisis showed that individuals have a low average financial literacy. This result is also different from the one reported by Villagómez (2014) who evaluated the level of financial literacy in young people of middle secondary level. Their results show that they do not have financial knowledge, in particular women and students who are enrolled in public schools. 
Likewise, the results do not provide evidence to support the thesis of Roa, Garrón and Barboza (2018), who points out that mathematical thinking skills are closely related to making reasoned financial decisions, which favor the future well-being of people. The relevance of economic and financial education topics in Mexico arises from the 2008 crisis in the United States that affected the Mexican economy. This generates the need for people to have culture and financial knowledge, as pointed out by Martínez-Morales and Franco-Flores (2016).

The issue of financial literacy, knowledge and culture, among other topics associated with financial education and inclusion, is very important and necessary for the population. It is clear that the empirical evidence has shown that even in populations of higher-level students who have had training in certain financial topics, these have not been clearly understanding, an example, the result reported by Moreno-García, García-Santillán and Gutiérrez-Delgado (2017) whose conclude that college students do not know how to calculate interest rates, they cannot interpret the information related to the price of bonds, which are related to interest rates, in summary, they point out that college student surveyed have a low level of financial education.

In relation to the cross-tab show the frequency of responses in certain aspects of the variables: saving, credit, and budget management, where we can observe that the frequency of responses to each indicator is higher in women than men. In addition, the result of the one-way ANOVA and Levene's test of homogeneity of variances provided evidence to say that in some indicators there is a difference in its means and population variances. These indicators are: "What is savings", "What is the main reason why what you save or would save", "What is the maximum time of your income that you should allocate to pay your credit cards", "You know how your monthly income is composed" and if you plan the distribution of your money", these indicators differ by gender in their means.

These results are not consistent with the findings reported by Pacheco and Yaruro (2017), who studied the factors that influence the use of financial products with data from the Survey for the Measurement of Financial Capabilities in the Andean Countries. Their findings indicate that the average of people with higher education with a high income level, has a greater propensity to know and have a financial product, and age and gender do not make a difference in these variables analyzed.

Finally, we can say that financial education and inclusion has continued to be a topic on the world agenda of the most powerful countries in the world, as well as the rest of the nations. Which means that the all empirical studies develop on this theoretical construct, add to the field of knowledge on the subject.

Several findings have made it possible to characterize the level of literacy, culture, and financial knowledge in certain populations, for example, the seminal works of Bernheim, Garrett, and Maki (2001), Lusardi and Mitchell (2011) who have contributed significant advances in this field.

In addition, the effort that has been made in educational institutions around the world, with the inclusion of these topics in academic programs at different levels, has yielded great results. The truth is that the topic of financial education is broad and covers topics, from the basics to the management of derivative products and those that are traded in the international capital markets.

It is important insist for the inclusion of financial topics in the contents of the study programs, from the basic levels to the university level. Promote a financial culture, through the knowledge, use, and application of financial instruments brings with it a greater financial inclusion of the student population. Without a doubt, with these actions, the student population will acquire greater skill in the use and management of financial tools, which leads to making more reasoned financial decisions, no matter how simple.

\section{Future research}

It is necessary to continue exploring the levels of financial education in elementary, secondary, baccalaureate, bachelor, and post-degree students, in order to get a greater number of participants to achieve greater representativeness and impact of the findings. On the other hand, it is necessary to continue developing studies to measure the level of financial education in the population, since with the findings; actions can be taken to carry out their implementation, with the purpose of increasing their knowledge and being able to take better decisions throughout life. 


\section{References}

Adams, Rau, 2011 - Adams, G.A., Rau, B.L. (2011). Putting off tomorrow to do what you want today: Planning for retirement. American Psychologist. 66(3): 180-192. DOI: https://doi.org/10.1037/aoo22131

Álvarez, 2018 - Álvarez, C. (2018). Financial inclusion becomes part of the G20's agenda [Electronic resource]. URL: https://www.bbva.com/en/financial-inclusion-becomes-part-g2osagenda/

Bernheim et al., 2001 - Bernheim, B.D., Garrett, D.M., Maki, D.M. (2001). Education and saving: The long-term effects of high school financial curriculum mandates. Journal of Public Economics. 80(3): 435-465. DOI: https://doi.org/10.3386/w6085

ConsolidatedCredit, 2021 - ConsolidatedCredit (2021). Test de Educación Financiera. [Electronic resource]. URL: https://bit.ly/3uBlypp

Cruz-Vargas et al., 2017 - Cruz-Vargas, B.G., Díaz-Navarro J.C., Célleri-Zúñiga, M.N. (2017). Educación Financiera [Financial education]. Revista Publicando. 3(9): 740-751. [in Spanish]

Del Río-Chivardi et al., 2019 - Del Río-Chivardi, M.A., Suárez-Luengas, J., CastroSolares, C.E. (2019). Alfabetización Financiera en México [Financial Literacy in Mexico]. Estudios de Inclusión Financiera. Comisión Nacional Bancaria y de Valores. (1): 1-30. [in Spanish]

Hair et al., 1998 - Hair, J.F., Anderson, R.E., Tatham, R.L., Black, W.C. (1998). Multivariate data analysis (5th ed.). Upper Saddle River, NJ: Prentice Hall.

Jianakoplos, Bernasek, 1998 - Jianakoplos, N.A., Bernasek, A. (1998). Are women more risk averse? Economic Inquiry. 36(4): 620-630. DOI: https://doi.org/10.1111/j.1465-7295.1998.tbo1740.x

Lusardi, Mitchell, 2011 - Lusardi A., Mitchell, O.S. (2011). Financial Literacy around the world an overview. National Bureau of Economic Research. 1-19.

Lusardi, Mitchell, 2014 - Lusardi, A., Mitchell, O.S. (2014). The Economic Importance of Financial Literacy: Theory and Evidence. Journal of Economic Literature. 52(1): 5-44. DOI: https://doi.org/10.1257/jel.52.1.5

Martínez-Morales, Franco-Flores, 2016 - Martínez-Morales, J., Franco-Flores, E. (2016). El alfabetismo financiero: un análisis en el nivel medio superior y superior [Financial literacy: an analysis at senior high school and university]. Revista Administración y Finanzas. 3(6): 15-20. [in Spanish]

Moreno García et al., 2017 - Moreno García, E., García-Santillán, A., Gutiérrez-Delgado, L. (2017). Nivel de educación financiera en escenarios de educación superior. Un estudio empírico con estudiantes del área económico-administrativa [Level of financial education in higher education settings. An empirical study with students from the economic-administrative area]. Revista Iberoamericana de Educación Superior. 8(22): 163-183. [in Spanish]

Moreno, 2020 - Moreno, L.A. (2020). Test de Educación Financiera: ¿Cuánto sabes? [Financial Education Test: How much do you know?]. [Electronic resource]. URL: https://bit.ly/ 322Gh9e [in Spanish]

Pacheco, Yaruro, 2017 - Pacheco, D.J., Yaruro, A.M. (2017). Factores que afectan la tenencia de productos financieros en Colombia [Factors that affect the holding of financial products in Colombia]. Revista del Banco de la República. 90(1072): 17-40. [in Spanish]

Roa et al., 2018 - Roa, M.J., Garrón, I., Barboza, J. (2018). Capítulo 7. Características cognitivas, rasgos de personalidad y alfabetización financiera: papel en las decisiones financieras [Cognitive characteristics, personality traits and financial literacy: role in financial decisions]. En M.J. Roa y D. Mejía (Eds.). Decisiones financieras de los hogares e inclusión financiera: evidencia para América Latina y el Caribe (pp. 167-255). Centro de Estudios Monetarios Latinoamericanos CEMLA. [in Spanish]

Starček, Trunk, 2013 - Starček, S., Trunk, A. (junio, 2013). The Meaning and Concept of Financial Education in the Society of Economic Changes. Paper presented at Active citizenship by knowledge management \& innovation: proceedings of the Management, Knowledge and Learning International Conference (MakeLearn), Zadar, Croatia.

Van Rooij et al., 2011 - Van Rooij, M., Lusardi, A., Alessie, R. (2011). Financial literacy and stock market participation. Journal of financial Economics. 101(2): 449-472.

Villagómez, 2014 - Villagómez, A. (2014). Alfabetismo financiero en jóvenes mexicanos de 15 a 18 años [Financial literacy in young Mexicans ages 15 to 18]. Repositorio Digital CIDE. [Electronic resource]. URL: http://hdl.handle.net/11651/849 [in Spanish] 
Zamora-Lobato et al., 2016 - Zamora-Lobato, T., Moreno-García, E., Córdova-Rangel, A., García-Santillán, A. (2016). El nivel de educación financiera de los jóvenes de bachillerato y su influencia en la percepción que tienen de las instituciones financieras. Un estudio empírico en Xalapa, Veracruz [The level of financial education of high school youth and its influence on their perception of financial institutions. An empirical study in Xalapa, Veracruz]. Editors \& Publisher: Les dernières publications de l'ISEOR, Francia y USA. [in Spanish]

\section{Appendix}

\section{FINANCIAL LITERACY QUESTIONNAIRE}

The purpose of the following questionnaire is to collect information related to the level of financial education that young people have in financial topics. It is important to mention that all the answers mentioned here are completely reliable and will only be used in this investigation. It is required to obtain information on the profile of the respondent and the management they have in the administration of their finances.

We appreciate the support that is provided in these short minutes.

Select an option

1. Gender: Male ( ) Female ()

2. Age: ___ years

3. Marital Status Do you live with your partner in a free union?

( ) Is separated ___ ( ) Divorced___ Married___ Single

4.- Currently, what is your employment status?

You currently work ( ) You do not have a job ( ) You only study ( ) You study and you work ( )

5. How much do you earn or receive for your work, activity or business?

( ) Less than $\$ 1,500$

( ) From $\$ 1,500$ to $\$ 3,000$

( ) From $\$ 3,000$ to $\$ 4,999$

( ) From $\$ 5,000$ to $\$ 7,999$

6. What is savings?

a) Save money.

b) Have money for emergencies.

c) Something for the future.

d) Do not spend.

e) Have money available.

f) Money in the bank.

g) Financial security.

h) Money accumulated to buy.

7. What is the main reason you save or would save?

a) Save it.

b) Personal expenses.

c) For old age.

d) When there is no work.

e) Education.

8. How often do you read or learn about savings, investments, credit, and retirement funds?

( ) Always

( ) Occasionally

( ) Never

9.- How much money should you put into your savings each month?

( ) $2 \%$ of your income

( ) $10 \%$ of your salary

( ) All the money you have left at the end of the month 
( ) Any low-denomination banknote that you have or are found.

10. For you, credit is ...
a) A loan
b) A debt
c) A problem
d) A financial aid
e) I don't know

11. Do you have any type of credit?
a) Yes
b) No

12. What is the main risk of requesting a loan?
a) Failure to pay and lose equity
b) Pay high interest or increased interest
c) Get into debt

13. Do you have a credit card?
a) Yes
b) $\mathrm{No}$

14. If the previous answer is affirmative, select with how many of them?
a) 1 or 2
b) 3 or 4
c) 5 or 6
d) It does not have any

15. What is the maximum time of your income that you should use to pay your credit cards?
a) None
b) Everything you need to pay your debts in full each month
c) No more than $10 \%$ of all income
d) No more than $30 \%$ of your net income

16. What is the maximum debt-to-income ratio you should have to maintain financial stability?
a) Not more than $27 \%$
b) Not more than $41 \%$
c) Not more than $50 \%$
d) As long as you have more money than debt, that's okay!

17. How do you prefer to handle your money?
a) Cash
b) Credit card
c) Debit card

18. Do you know how your monthly income is composed?
a) Yes
b) No

19. Do you usually keep a record of your debts, expenses, income and savings?

a) If yes mention which ones?

b) No

20. Do you plan a distribution of your money?
a) Yes
b) No

Thanks for your support 